\title{
FATIGUE CRACK PROPAGATION RATE OF AUSTENITIC HIGH MANGANESE STEEL
}

\author{
Takeshi MORI ${ }^{1}$ and Atsushi ICHIKAWA ${ }^{2}$ \\ 1 Member of JSCE, Dr. of Eng., Associate Professor, Dept. of Civil Eng., Hosei University (kajino-cho 3, Koganei- \\ shi, Tokyo 184, Japan) \\ ${ }^{2}$ Member of JSCE, Chief Researcher, Bridge Laboratory, Railway Technical Research Institute (Hikari-cho 2, \\ Kokubunji-shi, Tokyo 185, Japan)
}

\begin{abstract}
The construction of Yamanashi test line for super conducting magnetic levitation vehicle system (Maglev) is advancing, and Maglev is planned to be adopted for Chuo-Shinkansen. Austenitic high manganese steels are intended to be used for the structures. In this study, the fatigue crack propagation rate of this type of steel and the influence of stress ratio and residual stress on this rate are experimentally investigated, and the results are compared with those of carbon or low alloy structural steels. On the basis of the above examinations, the expression representing the rate is proposed.
\end{abstract} Key Words : fatigue crack propagation rate, austenitic high manganese steel, stress ratio, residual
stress

\section{INTRODUCTION}

The construction of Yamanashi test line for super conducting magnetic levitation vehicle system (Maglev) is advancing, and Maglev will be the system to operate Chuo-Shinkansen. If ferrite-pearlite steels or martensite steels are used as structural materials for the facilities of Maglev, the problem will be caused that levitation and propulsion of the vehicle are disturbed by strong magnetism. It is effective for solving this problem to use low magnetism steels ${ }^{1)}$.

Austenitic high manganese steels and austenitic stainless steels are typical as low magnetism steels. The former have advantages in high strength, stable low magnetism and low price as compared with the latter. However, there are no records of the austenitic high manganese steels being used for the structures such as bridges though they were used for rail, caterpillar and so on as abrasion resistant steels. In order to use the austenitic high manganese steels as structural materials, it is necessary to clarify their mechanical properties, workability, properties of welded joints, various fracture properties and so on. In this study, fatigue crack propagation rate of an austenitic high manganese steel is examined particularly.

Numerous studies have been reported on the fatigue crack propagation rates $(\mathrm{da} / \mathrm{dN})$ of general structural steels, and much information has been gained. For instance, da/dN can be given as a function of stress intensity factor range $(\Delta K)^{2}$ ), the $\mathrm{da} / \mathrm{dN}$ is affected by mean stress and residual stress, this phenomenon is related to crack opening and closing ${ }^{3)}$, and the $\mathrm{da} / \mathrm{dN}-\Delta \mathrm{K}$ relationships of the general structural steels are almost identical regardless of their static strength. Based on these results, the $\mathrm{da} / \mathrm{dN}-\Delta \mathrm{K}$ relationships of general structural steels used for fatigue assessments are shown in some fatigue design $\operatorname{codes}^{4)-7 \text { ). }}$.

The austenitic high manganese steels, compared with the general structural steels, have properties such as high ductility, low yield ratio, remarkable work-hardening and so on. Considering such a difference in the deformation properties, the possibility is high that the fatigue crack propagation rate depending on the deformation and fracture properties in the crack tip will differ between the austenitic high manganese steels and the general structural steels.

In this paper, the influence of mean stress and residual stress on the fatigue crack propagation rate of the austenitic high manganese steel is clarified experimentally, and an equation of fatigue crack propagation rate is compared with general structural steels. On the basis of the results of above examinations, the equation of $\mathrm{da} / \mathrm{dN}-\Delta \mathrm{K}$ relationship is proposed for fatigue assessment of the manganese steel. 
Table 1 Chemical compositions and mechanical properties of the steel

\begin{tabular}{|c|c|c|c|c|c|c|c|}
\hline $\mathrm{C}$ & $\mathrm{Si}$ & $\mathrm{P}$ & $\mathrm{S}$ & $\mathrm{Ni}$ & $\mathrm{Cr}$ & $\mathrm{N}$ & $\mathrm{Mn}$ \\
\hline 0.60 & 0.30 & 0.025 & 0.001 & 2.00 & 2.00 & 0.019 & 14.14 \\
\hline
\end{tabular}

\begin{tabular}{|c|c|c|}
\hline yield point & tensile strength & elongation \\
\hline $358 \mathrm{MPa}$ & $926 \mathrm{MPa}$ & $73 \%$ \\
\hline
\end{tabular}

Table 2 TIG dressing condition

\begin{tabular}{|c|c|}
\hline current & $240 \mathrm{~A}$ \\
\hline voltage & $17 \mathrm{~V}$ \\
\hline speed & $25 \mathrm{~cm} / \mathrm{min}$ \\
\hline shield gas & $100 \% \mathrm{Ar}$ \\
\hline flow rate of gas & $25 \mathrm{1} / \mathrm{min}$ \\
\hline electrode size & $2.4 \mathrm{~mm}$ \\
\hline $\begin{array}{c}\text { projecting length of } \\
\text { electrode }\end{array}$ & $2.5 \mathrm{~mm}$ \\
\hline
\end{tabular}

Table 3 Fatigue test condition

\begin{tabular}{|c|c|c|c|c|}
\hline specimen & load range & stress ratio & a range of $\Delta \mathrm{K}$ & remarks \\
\hline B-1 & constant & 0.02 & $22 \sim 50 \mathrm{MPa}$ & \\
\hline B-2 & constant & 0.50 & $14 \sim 38 \mathrm{MPa}$ & \\
\hline B-3 & $\begin{array}{c}\text { decreasing and } \\
\text { increasing }\end{array}$ & $0.02 \sim 0.03$ & $13 \sim 29 \mathrm{MPa}$ & constant min. load $(1 \mathrm{kN})$ \\
\hline B-4 & decreasing & $0.31 \sim 0.91$ & $3.5 \sim 18 \mathrm{MPa}$ & constant max. load $(80 \mathrm{kN})$ \\
\hline T-1 & constant & 0.02 & $15 \sim 47 \mathrm{MPa}$ & \\
\hline T-2 & constant & 0.50 & $13 \sim 37 \mathrm{MPa}$ & \\
\hline T-3 & decreasing & $0.02 \sim 0.11$ & $4.3 \sim 17 \mathrm{MPa}$ & constant mini. load $(1 \mathrm{kN})$ \\
\hline T-4 & decreasing & $0.32 \sim 0.93$ & $3.3 \sim 18 \mathrm{MPa}$ & constant max. load $(80 \mathrm{kN})$ \\
\hline
\end{tabular}

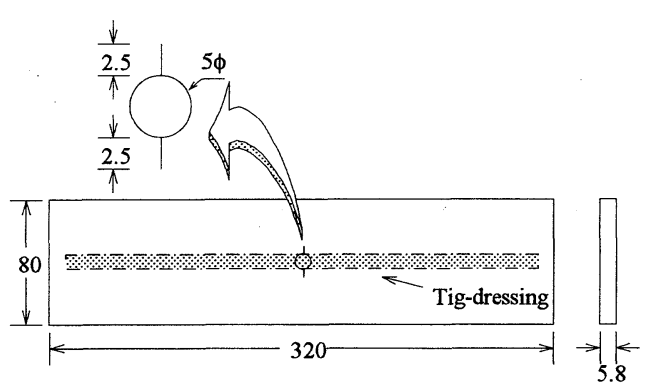

Fig.1 Configution and dimensions of specimen

\section{SPECIMEN}

The steel used was an austenitic high manganese steel KNM295 with a plate thickness of $5.8 \mathrm{~mm}$. The chemical compositions and mechanical properties of this steel by mill sheet are given in Table 1. This steel is about 1.5 times as high in tensile strength and about 2 times as large in elongation as a welding structural steel JIS SM490 which has a nearly equal yield point to this steel.

The specimens were cut out from the plate of this steel to a rectangle of $80 \mathrm{~mm}$ in width and $380 \mathrm{~mm}$ in length. The specimens were in two types. One was TIG dressed, and the other was base metal. TIGdressing was done under the conditions indicated in Table 2 on both faces of specimen along the middle of the plate width. This was done so that a tensile residual stress might be developed in the middle of the plate width. The base metal specimens were ascut. A circular hole of $5 \mathrm{~mm}$ in diameter was bored in the center of each rectangular plate, and notches of about $1 \mathrm{~mm}$ in width were cut from the wall of the hole with a diamond twist saw. These specimens were then submitted to fatigue crack propagation tests. The configuration and dimensions of these specimens are shown in Fig.1.

Before the fatigue crack propagation tests, the residual stress was measured in the longitudinal direction of the specimen on the section where the fatigue crack would propagate. The measurement was performed, mounting strain gages of $1 \mathrm{~mm}$ long on both faces of a specimen at intervals of $12 \mathrm{~mm}$, cutting peripheries of the gages, and measuring the difference in strains before and after the cutting. This measurement was done before boring the circular hole in the specimen. The measured results of residual stresses are shown in Fig.2. The value shown in the figure is average one for both faces of specimen. While a high tensile residual stress of about $250 \mathrm{MPa}$ is developed in the middle of the TIG dressed specimen, that of the base metal specimen is less than about one tenth of the former.

\section{PROCEDURE OF FATIGUE CRACK PROPAGATION TESTING}

Fatigue crack propagation tests were carried out using an electro-hydraulic servo fatigue testing machine with a dynamic capacity of $100 \mathrm{kN}$. The load wave forms were sine with repetition rates from 4 to $15 \mathrm{~Hz}$. A traveling microscope of 50 magnifications with an accuracy of $0.01 \mathrm{~mm}$ was used for the 


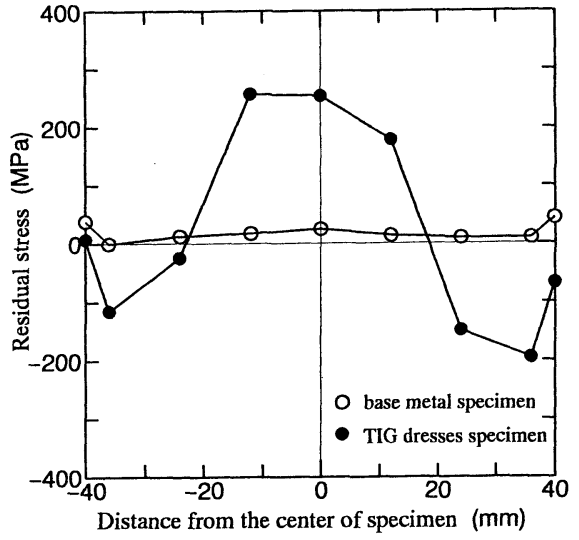

Fig.2 Measured residual stress distribution

measurement of crack length.

Four base metal specimens (B-1 B-4) and four TIG dressed specimens (T-1 T-4) were used for the fatigue crack propagation tests. The test conditions of each specimen are shown in Table 3. B-1, T-1, B2 and T-2 specimens were submitted to the fatigue propagation tests under constant amplitude loading. Stress ratio was nearly 0 for each specimen of B-1 and $\mathrm{T}-1$ [minimum load : $1 \mathrm{kN}$, load range : $54 \mathrm{kN}$ (B1), $48 \mathrm{kN}(\mathrm{T}-1)]$. As for $\mathrm{B}-2$ and $\mathrm{T}-2$ specimens, stress ratio was 0.5 [load range : $40 \mathrm{kN}$ ]. Fatigue crack propagation rates can be measured in the range of stress intensity factor range $(\Delta K)$ roughly from 15 to $50 \mathrm{MPa} \sqrt{\mathrm{m}}$ under such conditions. As for B-3, B4, T-3 and T-4 specimens, the load range was reduced stepwise together with crack length in order to examine low propagation rates at smaller $\Delta \mathrm{K}$ and those close to fatigue crack propagation threshold value $\left(\Delta \mathrm{K}_{\mathrm{th}}\right)$. In that case, the load ranges of $\mathrm{B}-3$ and $\mathrm{T}-3$ specimens were reduced stepwise under the constant minimum load of $1 \mathrm{kN}$, and those of B-4 and $\mathrm{T}-4$ specimens were also reduced stepwise under the constant maximum load of $80 \mathrm{kN}$. The minimum load and maximum load were kept constant respectively. The reduction of load range was less than 5 percent in one step, and the interval was set at about every $0.25 \mathrm{~mm}$ of crack propagation. As for the B-3 specimen, the load range was also increased stepwise by 5 percent after $\Delta \mathrm{Kth}$ was measured.

The influence of stress ratio on the fatigue crack propagation rate is examined by comparing the test results of B-1 $-\mathrm{B}-3$ specimens with those of $\mathrm{B}-2 \cdot \mathrm{B}-4$ specimens, or those of $T-1 \cdot T-3$ specimens with those of T-2 $\cdot \mathrm{T}-4$ specimens. The influence of residual stress is examined by comparing the test results of B$1 \cdot B-3$ specimens with those of $T-1 \cdot T-3$ specimens, or those of $\mathrm{B}-2 \cdot \mathrm{B}-4$ specimens with those of $\mathrm{T}-2 \cdot \mathrm{T}-4$

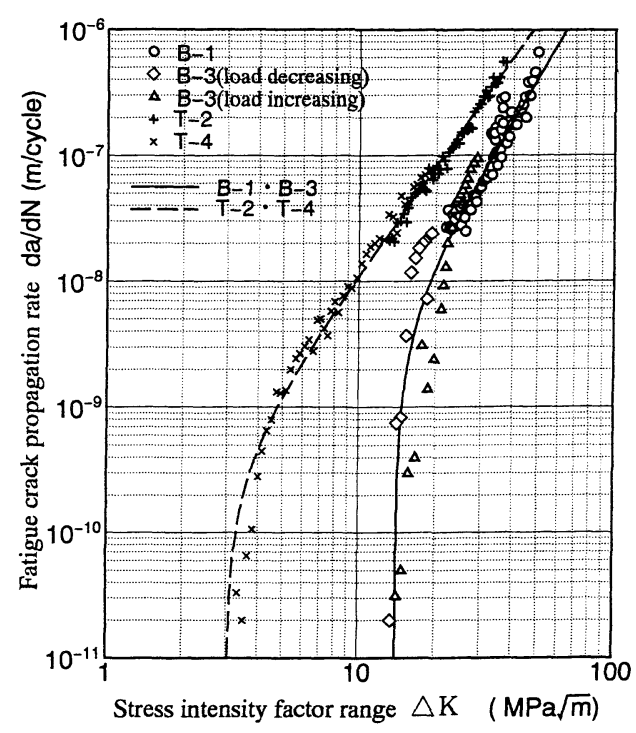

Fig.3 An example of da/dN- $\Delta \mathrm{K}$ relationship

specimens.

The behaviors of crack opening and closing were observed by examining the relationship between strain and load ${ }^{8}$. The strain was measured by strain gage (gage length : $6 \mathrm{~mm}$, gage width : $1 \mathrm{~mm}$ ) mounted on the surface near the crack tip. The gauge center was set at $2 \mathrm{~mm}$ from the crack tip toward the crack side and cellophane tape of $3 \mathrm{~mm}$ in width was inserted between the gage and the specimen.

\section{TEST RESULTS}

\section{(1) Method of processing test results}

Fig. 3 shows the relationships between fatigue crack propagation rate $(\mathrm{da} / \mathrm{dN})$ and stress intensity factor range $(\Delta K)$, which are obtained from fatigue crack propagation tests of B-1 $\bullet B-3$ specimens and $T-2 \cdot T-4$ specimens. The value of $\Delta K$ was calculated by using Tada's equation ${ }^{9}$ ). It is well known that the $\mathrm{da} / \mathrm{dN}$ $\Delta \mathrm{K}$ relationship of the general structural steels is given by the Eq.(1).

$$
\begin{gathered}
\mathrm{da} / \mathrm{dN}=\mathrm{C}\left(\Delta \mathrm{K}^{\mathrm{m}}-\Delta \mathrm{K}_{\mathrm{th}} \mathrm{m}\right) \\
\mathrm{C} \text { and } \mathrm{m}: \text { constants }
\end{gathered}
$$

$\Delta \mathrm{K}_{\text {th }}$ : threshold stress intensity factor range

The $d a / d N-\Delta K$ relationship of the austenitic high manganese steel obtained in this study has a similar shape to that given by the Eq.(1) as shown in Fig.3. The constants $\mathrm{C}, \mathrm{m}$, and $\Delta \mathrm{K}_{\text {th }}$ in the Eq.(1) are obtained according to the following procedures.

(1) The values of $\mathrm{C}$ and $\mathrm{m}$ are calculated by regression analysis, in which the independent variable is 

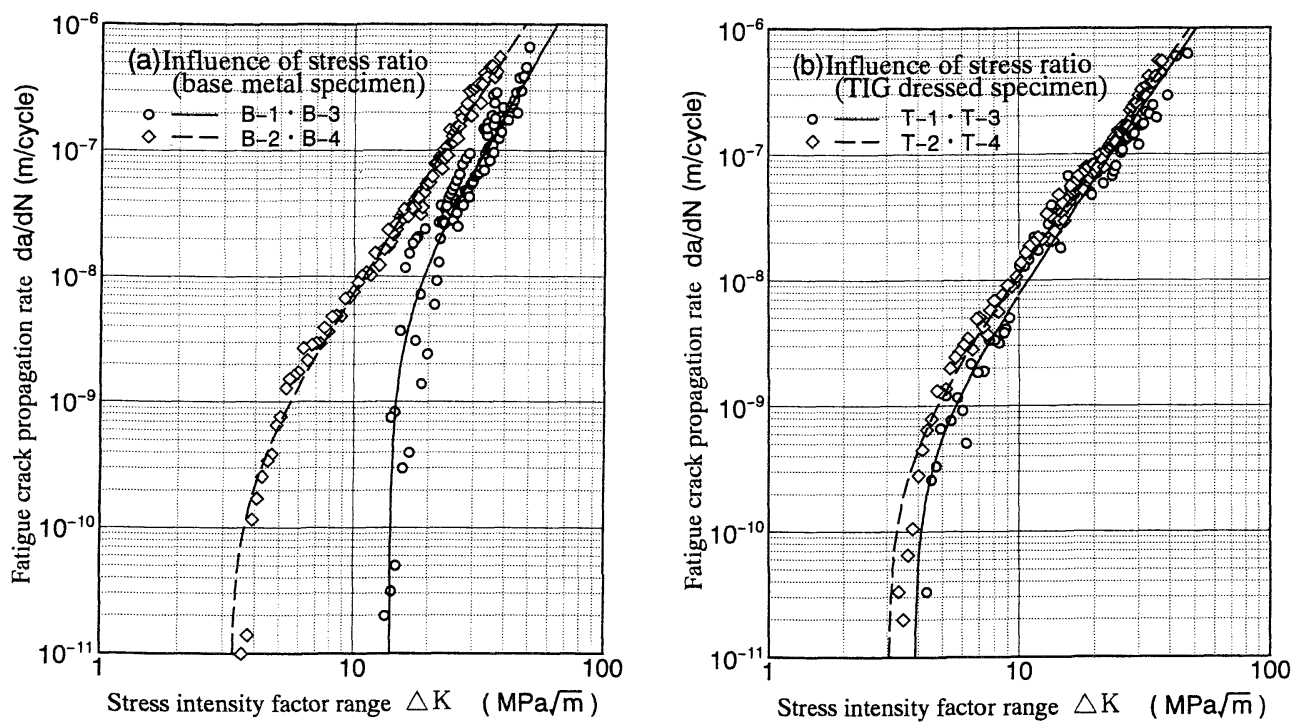

Fig.4 Influence of stress ratio on $\mathrm{da} / \mathrm{dN}-\Delta \mathrm{K}$ relationship

$\mathrm{da} / \mathrm{dN}$, a least squares method is used and the data are utilized in a range where the $\mathrm{da} / \mathrm{dN}-\Delta \mathrm{K}$ relationship indicates linearity in terms of logarithms. In this calculation, $\Delta \mathrm{K}_{\mathrm{th}}$ is assumed to be 0 . It is judged that the $\mathrm{da} / \mathrm{dN}-\Delta \mathrm{K}$ relationship of $\mathrm{B}-1 \cdot \mathrm{B}-3$ specimens indicates linearity in terms of logarithms in a region of $\mathrm{da} / \mathrm{dN} \geqq 10^{-8} \mathrm{~m} /$ cycle and that of $\mathrm{T}-2 \cdot \mathrm{T}-4$ specimens does so in a region of $\mathrm{da} / \mathrm{dN} \geqq 10^{-9} \mathrm{~m} /$ cycles The $\mathrm{da} / \mathrm{dN}-\Delta \mathrm{K}$ relationship of $\mathrm{B}-2 \cdot \mathrm{B}-4$ specimens and that of $\mathrm{T}-1 \cdot \mathrm{T}-3$ specimens are also treated as linear in terms of logarithms in a region of $\mathrm{da} / \mathrm{dN} \geqq$ $10^{-9} \mathrm{~m} /$ cycles.

(2) The values of $\mathrm{C}$ and $\mathrm{m}$ obtained from (1) are applied to the Eq.(1). And the value of $\Delta \mathrm{K}_{\mathrm{th}}$ is obtained, changing the value of $\Delta \mathrm{K}_{\mathrm{th}}$, by minimizing the square sum of differences between the calculated values of $\Delta \mathrm{K}$ obtained from the Eq.(1) for a certain $\mathrm{da} / \mathrm{dN}$ value and the experimental values.

The $\mathrm{da} / \mathrm{dN}-\Delta \mathrm{K}$ relationships of $\mathrm{B}-1 \cdot \mathrm{B}-3$ specimens and those of $\mathrm{T}-2 \cdot \mathrm{T}-4$ specimens, which are obtained by the above-mentioned method, are shown with a solid line and a broken line in Fig.3 respectively. As for the B-3 specimen, after the crack propagation rate of about $10^{-11} \mathrm{~m} /$ cycle was measured in the load range decreasing test, the propagation rate was measured in the load range increasing test. Both the propagation rates almost agree each other, so it is considered that the condition of load range decreasing tests here is appropriate.

\section{(2) Influence of mean stress and residual stress}

The relationships between fatigue crack propagation rate $(\mathrm{da} / \mathrm{dN})$ and stress intensity factor range
$(\Delta \mathrm{K})$ obtained from the fatigue crack propagation tests, in which the stress ratio is varied, are shown in Figs.4(a) and (b). As for the base metal specimens shown in Fig.(a), the crack propagation rate at high stress ratio in a range where $\Delta \mathrm{K}$ is comparatively large is about four times as large as that at low stress ratio. The difference in them becomes still larger as $\Delta \mathrm{K}$ becomes smaller. The threshold stress intensity factor range $\left(\Delta \mathrm{K}_{\mathrm{th}}\right)$ is $14.0 \mathrm{MPa} \sqrt{\mathrm{m}}$ at low stress ratio and $3.2 \mathrm{MPa} \sqrt{\mathrm{m}}$ at high stress ratio. The latter decreases to one fourth or less of the former. On the other hand, as for the TIG dressed specimens shown in Fig.(b), the crack propagation rate at high stress ratio is higher than that at low stress ratio, but the difference is very small compared with those of the base metal specimens.

Figs.5 (a) and (b) show the da/dN- $\Delta \mathrm{K}$ relationships of the base metal specimens and the TIG dressed specimens at almost the same stress ratio. At low stress ratio shown in Fig.(a), the crack propagation rate of the TIG dressed specimens with high tensile residual stress is higher than that of base metal specimens with little residual stress. The difference is especially remarkable in a range where $\Delta \mathrm{K}$ is small. $\Delta \mathrm{K}_{\text {th }}$ of the TIG dressed specimens is one fourth of that of the base metal specimens. On the other hand, at high stress ratio shown in Fig.(b), the difference of $\mathrm{da} / \mathrm{dN}-\Delta \mathrm{K}$ relationships between the base metal specimens and the TIG dressed specimens is not remarkable. The influence of mean stress and residual stress on the fatigue crack propagation rate, mentioned above, is similar to the results on the general structural steels ${ }^{8,10)-12)}$.

An example of the relationship between the output 

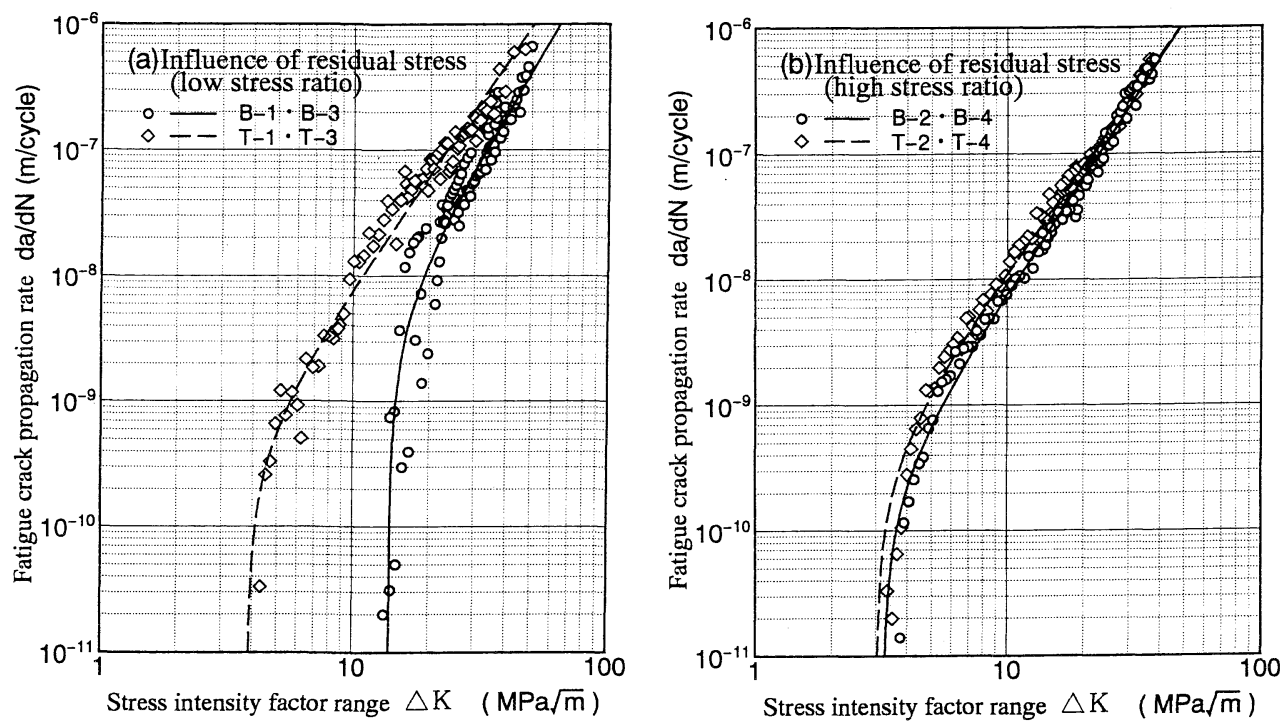

Fig.5 Influence of residual stress on $d a / d N-\Delta K$ relationship

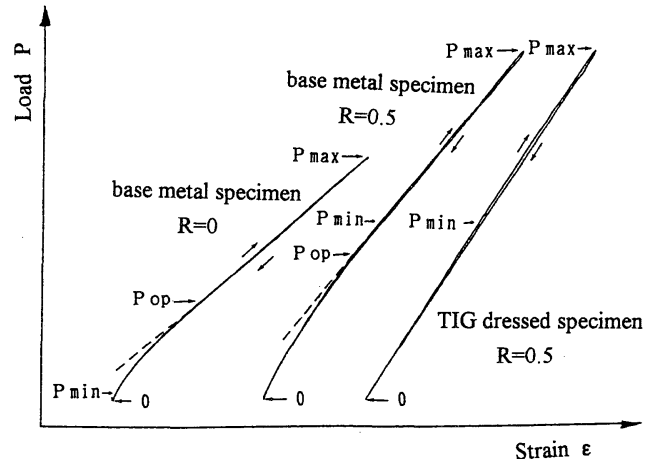

Fig.6 Load-strain curve

of strain gage and the load is shown in Fig.6. This relationship is utilized to measure the crack opening and closing point. $P_{\max }$ in the figure indicates a maximum load and $P_{\min }$ is a minimum load. In the TIG dressed specimen shown here, crack closure did not occur even though the testing load was 0 . In other TIG dressed specimens, the crack remained open under a load of 0 or more. On the other hand, in the base metal specimens the fatigue crack closure occurred under a load of 0 or more. However, in the B-2 specimen with stress ratio of 0.5 and in the B-4 specimen with high stress ratio and constant maximum load, the fatigue crack closure was not observed in a range of testing load. That is, only in the base metal specimens B-1 and B-3 at a stress ratio nearly equal to 0 , the fatigue crack closure was observed within the range of testing load. The results of measurements for the fatigue crack opening and closing points are shown in Fig.7.

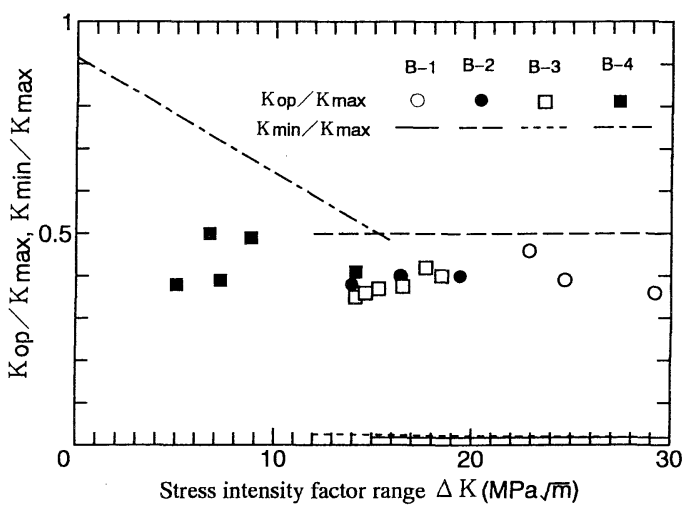

Fig.7 Crack opening stress intensity factor of base metal specimen

Effective stress intensity factor range $\left(\Delta \mathrm{K}_{\text {eff }}\right)$ was calculated based on the measured results of crack opening and closing behavior, and the relationships between fatigue crack propagation rate $(\mathrm{da} / \mathrm{dN})$ and $\Delta \mathrm{K}_{\text {eff }}$ is shown in Fig.8. In a range where the fatigue crack propagation rate is comparatively high, the relationship between $\mathrm{da} / \mathrm{dN}$ and $\Delta \mathrm{K}_{\text {eff }}$ with the B-1 and B-3 specimens in which crack closure occurred is similar to the relationship with other specimens in which crack closure did not occur. However, the threshold stress intensity factor range is considerably variable. As for the general structural steels, it is known that the cracks become easy to close in areas close to the threshold stress intensity factor range, because crack surfaces become rough and formation of oxide is induced by friction between the rough 


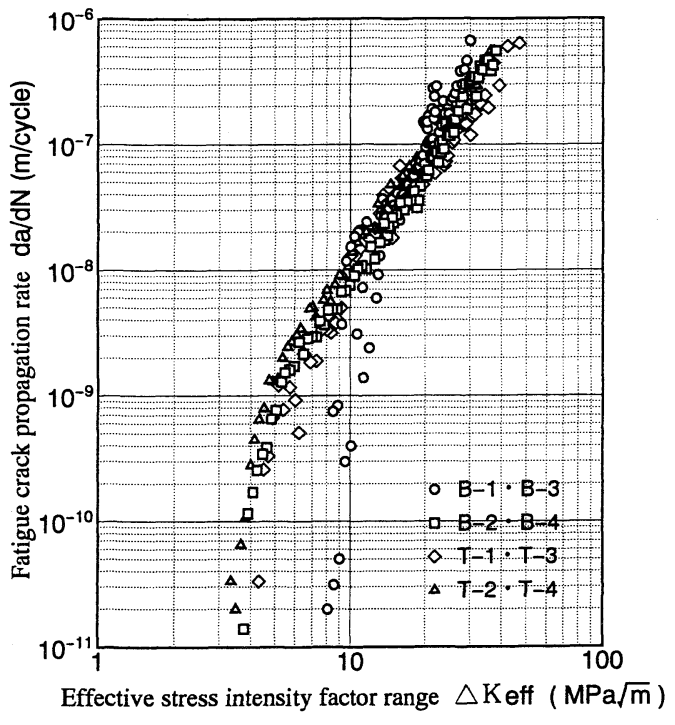

Fig.8 Relation between $\mathrm{da} / \mathrm{dN}$ and $\Delta \mathrm{K}_{\mathrm{eff}}$

surfaces $^{13)}$. However, crack opening ratios of the austenitic high manganese steel in the region close to the threshold stress intensity factor range becomes approximately constant as shown in Fig.7. Thus the crack opening ratios are almost the same in all $\Delta \mathrm{K}$ ranges, and the values of threshold stress intensity factor range arranged in terms of $\Delta \mathrm{K}_{\mathrm{eff}}$ are considerably different because of the presence of fatigue crack closure. This is thought to be the characteristic of the austenitic high manganese steels, but the details should be examined hereafter.

\section{5. da/dN- $\triangle K$ RELATIONSHIP USED FOR FATIGUE ASSESMENT}

Fig.9 shows the result of comparing da/dN- $\Delta \mathrm{K}$ relationship of the austenitic high manganese steel with that of the general structural steels under the condition that fatigue crack propagation rate rises to the limit, that is, the fatigue crack closure does not occur. The solid line in Fig. 9 shows the da/dN- $-\Delta \mathrm{K}$ relationship of general structural steels given by Tanaka et al. ${ }^{14)}$ after processing a lot of fatigue test data, and the broken line shows that given by Ohta et al. ${ }^{15)}$. The $\mathrm{da} / \mathrm{dN}-\Delta \mathrm{K}$ relationship by Tanaka et al. is based on the result of processing $\mathrm{da} / \mathrm{dN}$ data on the base metal specimens in terms of $\Delta \mathrm{K}_{\mathrm{eff}}$. The relationship by Ohta et al. is obtained in a high tensile residual stress field, that is, it is based on the test data under the condition that fatigue crack closure does not occur just as in this study. The $\mathrm{da} / \mathrm{dN}-\Delta \mathrm{K}$ relationship of the austenitic high manganese steel obtained in this study agrees well with

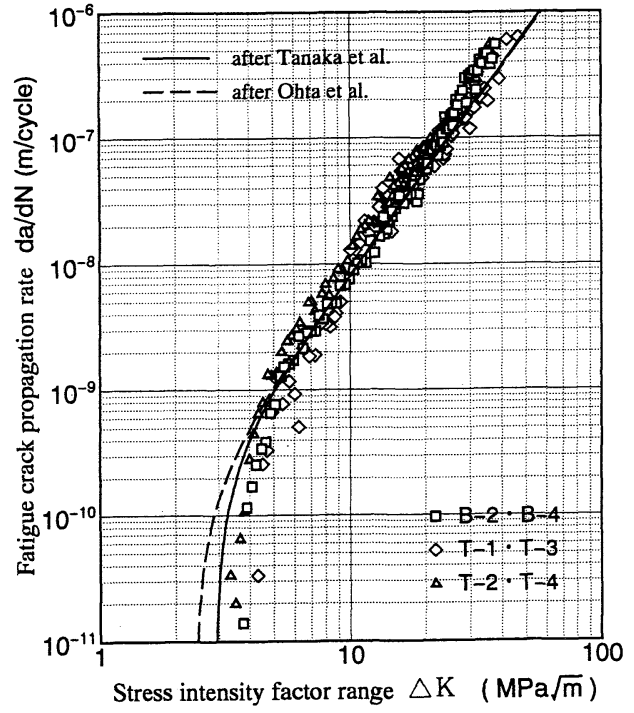

Fig.9 Comparison to da/dN- $\Delta \mathrm{K}$ relationship of general structual steel

that of the general structural steels in a range where $\Delta \mathrm{K}$ is comparatively large. However, the threshold stress intensity factor range $\left(\Delta \mathrm{K}_{\mathrm{th}}\right)$ which is the limit value of the fatigue crack propagation is slightly large compared with that of the general structural steels.

It would be reasonable to think that the equation of $\mathrm{da} / \mathrm{dN}-\Delta \mathrm{K}$ relationship of the austenitic high manganese steel used for the fatigue assessment should be determined on the basis of the results obtained under the condition that crack closure does not occur, that is, the fatigue crack propagation rate is the highest. It is because in actual structures crack closures sometimes do not occur due to welding tensile residual stress or restraint stress and so on. Therefore, a regression analysis of the data obtained from B-2, B-4, T-1, T-2, T-3 and T-4 specimens in which the crack closure did not occur was performed, and considering the result, the equation for the fatigue crack propagation rate of the austenitic high manganese steel is proposed as shown in Fig.10. The procedure of the regression analysis is the same as that in Chapter 4. The Eq.(2) is the expression for the fatigue crack propagation rate of the austenitic high manganese steel, which is proposed in this study.

$$
\begin{aligned}
& \mathrm{da} / \mathrm{dN}=9.3 \times 10^{-12}\left(\Delta \mathrm{K}^{3.0}-\Delta \mathrm{Kth}^{3.0}\right) \\
& \text { where, } \\
& \text { da/dN }: \mathrm{m} / \mathrm{cycle}, \Delta \mathrm{K}: \mathrm{MPa} \sqrt{\mathrm{m}} \\
& \Delta \mathrm{Kth}: 3.4 \mathrm{MPa} \sqrt{\mathrm{m}}
\end{aligned}
$$

The equation of the fatigue crack propagation rate shown in "Fatigue Design Recommendations for 


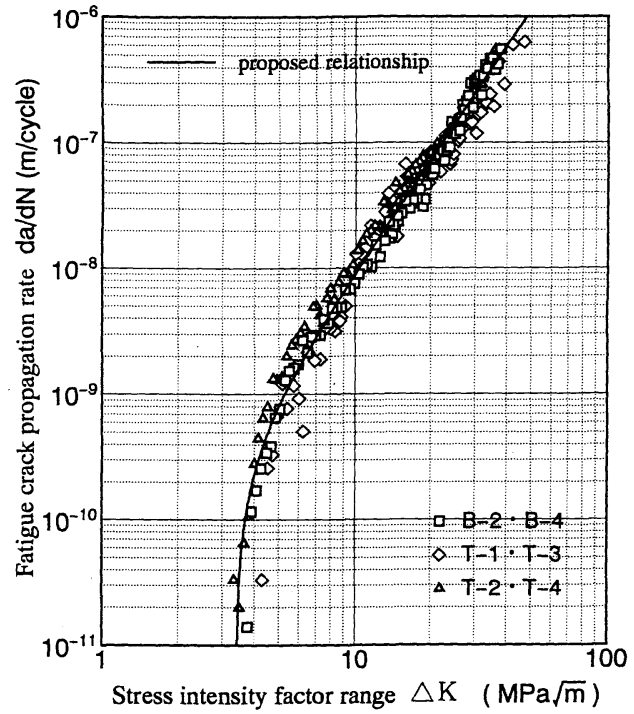

Fig.10 Proposed da/dN- $\Delta \mathrm{K}$ relationship

Steel Structures"4) by Japanese Society of Steel Construction (hereafter, it is referred to as the JSSC recommendations), which is given on the basis of abundant up-to-date data on the general structural steels, is considered the most reliable one at present. Fig.11 shows the result of comparing the fatigue test data of the austenitic high manganese steel obtained in this study with the equation of the fatigue crack propagation rate (average design curve and conservative design curve) proposed in the JSSC recommendations. The average design curve is the expression of fatigue crack propagation rate used when average fatigue strength or fatigue life is required, and the conservative design curve is the expression used when the similar degree of safety [(mean)-2x(standard deviation)] for the fatigue assessment is taken into consideration. The value of $\Delta \mathrm{K}_{\text {th }}$ is estimated somewhat larger in the average design curve. However, the curve is located almost at the center of the data in other regions. The value of $\Delta \mathrm{K}_{\text {th }}$ is also estimated somewhat larger in the conservative design curve. However, the curve is located almost in the upper bound of the data in other regions. Therefore, even though the design curve shown in the JSSC recommendations is used for the fatigue assessment of the austenitic high manganese steel, the estimate may be considered to lean not so far on the unsafe side.

\section{CONCLUSIONS}

(1) The influence of stress ratio and residual stress on the fatigue crack propagation rate of the austenitic

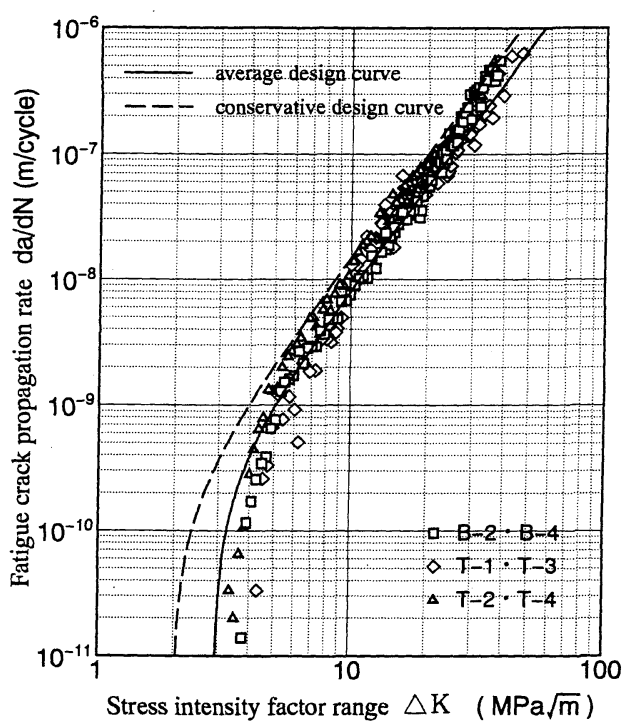

Fig.11 Comparison to da/dN- $\Delta \mathrm{K}$ relationship defined by JSSC recommendations

high manganese steel is the same as that of the general structural steels.

(2) The da/dN- $\Delta K$ relationship of the austenitic high manganese steel agrees with that of the general structural steels in a range where $\Delta \mathrm{K}$ is comparatively large, but the threshold stress intensity factor range $\Delta \mathrm{K}_{\text {th }}$ is slightly large.

(3) An equation of the fatigue crack propagation rate which should be used for the fatigue assessment of the austenitic high manganese steel is proposed.

where,

$$
\mathrm{da} / \mathrm{dN}=9.3 \times 10^{-12}\left(\Delta \mathrm{K}^{3.0}-\Delta \mathrm{K}_{\mathrm{th}}{ }^{3.0}\right)
$$

$$
\begin{aligned}
& \mathrm{da} / \mathrm{dN}: \mathrm{m} / \text { cycle, } \Delta \mathrm{K}: \mathrm{MPa} \sqrt{\mathrm{m}} \\
& \Delta \mathrm{K}_{\text {th }}: 3.4 \mathrm{MPa} \sqrt{\mathrm{m}}
\end{aligned}
$$

(4) Even though the equation of the fatigue crack propagation rate proposed by Japanese Society of Steel Construction is applicable to the fatigue assessment for the austenitic high manganese steel, the estimate does not lean so far on the unsafe side.

ACKNOWLEDGMENTS : The authors would like to express thanks to Mr. T. Kawakami (Fuji PS), Mr. Y. Awara (Toyama Prefecture Office), Mr. K. Nakajima (Hitachi Ship-Buildings) and Mr. S. Masuda (Daikyo), who were undergraduate students of Hosei University, for their assistance in the fatigue tests and in the processing of the experimental data. Thanks are also due to Mr. M. Iwasaki (Yokogawa Bridge) for fabricating specimens.

\section{REFERENCES}

1) Ichikawa,A., Murata,K., Anami,G. and Matsuura, A. : Study 
on Application of Austenitic High Manganese Steels to Maglev Guide way, Steel Construction Engineering, Vol.1, No.1, pp.63-72,1994 (in Japanese).

2) Paris, P. and Erdogan, F. : A Critical Analysis of Crack Propagation Laws, Transactions of ASME, Journal of Basic Engineering, Vol.85, pp.528-534, 1963.

3) Elber, W. : The Significance of Fatigue Crack Closure, ASTM STP486, pp.209-220, 1971.

4) Japanese Society of Steel Construction : Fatigue Design Recommendations for Steel Structures, Gihodo, 1993 (in Japanese).

5) Japanese Institution of Welding : Method of Assessment for Defects in Fusion Welded Joints in respect to Brittle Fracture, WES2805-1980, 1980 (in Japanese).

6) Det Norske Veritas : Fatigue Strength Analysis for Mobile Offshore Units, DNV Classification Notes, No.30.2, 1984.

7) British Standard Institution : Guidance on Some Methods for Derivation of Acceptance Levels for Defects in Fusion Welded Joints, BSI PD6493, 1980.

8) Miki,C., Mori,T. and Tajima,J. : Effect of Stress Ratio and Tensile Residual Stress on Near Threshold Fatigue Crack Growth, Proceeding of JSCE, No.368, pp.383-392, 1986.

9) Ishida,M. : Elastic Analysis of Crack and Stress Intensity Factor, Baifukan, 1976 (in Japanese).

10) Ohta,A., Sasaki,E. and Kosuge,M. : Effect of Stress Ratios on the Fatigue Crack Propagation Rate, Transactions of the
JSME, Vol.43, No.373, pp.3179-3191, 1977 (in Japanese).

11) Fukuda,S., Watari,S. and Horikawa,K. : Effect of Welding Residual Stress on Fatigue Crack Propagation (An Experimental Study with Attention Paid to Crack Opening and Closure), Transactions of JSME, Vol.47, No.416, pp.384390, 1981 (in Japanese).

12) Sakakibara,A., Horikawa,K and Mori,T. : Effect of Welding Tensile Residual Stresses on Fatigue Crack Propagation in Low Rate Region, Quarterly Journal of the Japan Welding Society, Vol.4, No.1, pp.193-199, 1986 (in Japanese).

13) Kobayashi,H. : Influence of Structure on Fracture Surface Morphology and Its Mechanics, Journal of the Materials Science Society of Japan, Vol.17, No.6, pp.282-291,1981 (in Japanese).

14) Tanaka,Y., Soya,I. : Fatigue Crack Propagation Behavior of Various Types of Steels for Welded Structures, Quarterly Journal of the Japan Welding Society, Vol.7, No.2, pp.90-97, 1989 (in Japanese).

15) Ohta,A., Maeda,Y., Kosuge,M., Machida,S. and Yoshinari,H. : Design Curve for Fatigue Crack Propagation in Weldments Containing Tensile Residual Stresses, Quarterly Journal of the Japan Welding Society, Vol.7, No.3, pp.107112,1989 (in Japanese).

(Received June 3, 1994)

\section{高マンガン鋼の疲労亀裂進展速度}

\section{森 猛・市川 篤司}

中央新幹線には超伝導磁気浮上式リニアモータカーシステムの使用が予定されており, その鋼構造物 に低磁性の高マンガン鋼の使用が検討されている. 鋼マンガン鋼は, 耐磨耗鋼としてレールやキャタピ ラなどに用いられており，橋梁などの構造物に使用された実績はない。本研究では, 高マンガン鋼を構 造物に適用するに当たって解明すべき問題の一つである疲労龟裂進展速度について実験的に検討し, 高 マンガン鋼の疲労照査に用いるべき疲労亀裂進展速度表示式を提案する. 